Theory into Practice 


\section{Theory into Practice}

A READER IN MODERN LITERARY CRITICISM

EDITED AND INTRODUCED

BY K. M. NEWTON

palgrave
macmillan 
Introduction, selection and editorial matter

(C) K. M. Newton 1992

All rights reserved. No reproduction, copy or transmission of this publication may be made without written permission.

No paragraph of this publication may be reproduced, copied or transmitted save with written permission or in accordance with the provisions of the Copyright, Designs and Patents Act 1988, or under the terms of any licence permitting limited copying issued by the Copyright Licensing Agency, 90 Tottenham Court Road, London W1P 9HE.

Any person who does any unauthorised act in relation to this publication may be liable to criminal prosecution and civil claims for damages.

First published 1992 by THE MACMILLAN PRESS LTD

Houndmills, Basingstoke, Hampshire RG21 2XS and London

Companies and representatives throughout the world

ISBN 978-0-333-56768-5 ISBN 978-1-349-22244-5 (eBook)

DOI 10.1007/978-1-349-22244-5

A catalogue record for this book is available from the British Library

Phototypeset by Intype, London

Logging, pulping and manufacturing processes are expected to conform to the environmental regulations of the country of origin. 


\section{CONTENTS}

Acknowledgements vii

Introduction 1

1 The New Criticism and Leavisite Criticism 8

Gleanth Brooks: 'Literary Criticism: Marvell's "Horatian Ode", 11

F. R. Leavis: 'Antony and Cleopatra and All for Love' 28

2 Formalism, Dialogism, Structuralism 39

Victor Shklovsky: 'The Mystery Novel: Dickens's Little Dorrit' 43

M. M. Bakhtin: 'Heteroglossia in the Novel' 50

David Lodge: 'Analysis and Interpretation of the Realist Text: Ernest Hemingway's "Cat in the Rain", , 58

3 Reader-Response $\quad 77$

Wolfgang Iser: 'The Role of the Reader in Fielding's Joseph Andrews' 80

Stanley Fish: 'Transmuting the Lump: Paradise Lost, 1942-1982'

4 Post-Structuralism

J. Hillis Miller: 'Thomas Hardy, Jacques Derrida, and the "Dislocation of Souls",

Gayatri Chakravorty Spivak: "'Draupadi" by Mahasweta Devi'

Catherine Belsey: 'Milton's Shorter Poems'

Shoshana Felman: 'The Case of Poe: Applications/

Implications of Psychoanalysis'

5 Gender and Race

Elaine Showalter: 'Representing Ophelia: Women, Madness, and the Responsibilities of Feminist Criticism'

Barbara Johnson: 'Is Female to Male as Ground Is to Figure?' 
vi CONTENTS

Henry Louis Gates, Jr: 'Binary Oppositions in Chapter One of Narrative of the Life of Frederick Douglass an American Slave Written by Himself

6 Politics and History

Terry Eagleton: 'Ideology and Literary Form: Joseph Conrad'

Stephen Greenblatt: 'The Cultivation of Anxiety: King Lear and His Heirs'

Alan Sinfield: 'Macbeth: History, Ideology and Intellectuals'

Edward W. Said: 'Jane Austen and Empire' 


\section{ACKNOWLEDGEMENTS}

The author and publishers wish to thank the following for permission to use copyright material:

Basil Blackwell Ltd for Edward W. Said, 'Jane Austen and Empire' in Raymond Williams: Critical Perspectives, ed. Terry Eagleton (Polity Press, 1989); and Catherine Belsey on some short poems of Milton from John Milton: Language Gender, Power (1988); Cornell University Press for Barbara Johnson, 'Is Female to Male as Ground is to Figure?' in Feminism and Psychoanalysis, eds Richard Feldstein and Judith Roof, copyright (C) 1985 by Cornell University; Columbia University Press for Cleanth Brooks, 'Literary Criticism: Marvell's "Horatian Ode", in The English Institute Essays (1946); Stephen Greenblatt for 'The Cultivation of Anxiety: King Lear and His Heirs', Raritan, 2, 1968; Harvard University Press for Shoshana Felman, 'The Case of Poe: Applications/Implications of Psychoanalysis', in Jacques Lacan and the Adventure of Thought: Psychoanalysis in Contemporary Culture (1987); copyright (C) 1987 by the President and Fellows of Harvard College; the Johns Hopkins University Press for Wolfgang Iser, 'The Role of the Reader in Fielding's Joseph Andrews' in The Implied Reader (1974); and J. Hillis Miller, 'Thomas Hardy, Jacques Derrida, and the 'Dislocation of Souls' in Taking Chances: Derrida, Psychoanalysis, and Literature eds William Herrigan and Joseph H. Smith (1984) and in Tropes, Parables, Performatives: Selected Essays on Twentieth Century Literature by J. Hillis Miller (Harvester Wheatsheaf, 1991); Oxford University Press, Inc., for Henry Louis Gates, Jr., 'Binary Oppositions' in Figures in Black: Words, Signs, and the 'Racial' Self copyright (C) 1987 by Henry Louis Gates, Jr.; Random Century Group and the Estate of F. R. Leavis for F. R. Leavis, 'Antony and Cleopatra and All for Love' in The Living Principle (1975, Chatto and Windus); Routledge for Elaine Showalter, 'Representing Ophelia' in Shakespeare and the Question of Theory, eds P. Parker and G. Hartman (Methuen, 1985); and material from David Lodge, Working with Structuralism (1981); Alan Sinfield for 'Macbeth: History, Ideology, Intellectuals', Critical Quarterly, 28, 1986; Stanford University Press for Stanley Fish, 'Transmuting the Lump: Paradise Lost 1942-1982' in Literature and History ed. Gary Saul Morson (1986); University of Chicago Press for Gayatri Chakrovorty Spivak, " 'Draupadi” by Mahasweta Devi', Critical Inquiry, 8, 


\section{viii AGKNOWLEDGEMENTS}

1981; University of Michigan, Department of Slavic Languages and Literatures, for Victor Shklovsky, 'The Mystery Novel: Little Dorrit' in Readings in Russian Poetics, eds. Ladislaw Matejka and Krystyna Pomorska (1978); University of Texas Press for M. M. Bakhtin, 'Heteroglossia in the Novel' in The Dialogic Imagination, ed. Michael Holquist, copyright (C) 1981 by the University of Texas Press; Verso for Terry Eagleton, 'Ideology and Literary Form: Joseph Conrad' in Criticism and Ideology: A Study in Marxist Literary Theory (New Left Books, 1976).

Every effort has been made to trace all the copyright-holders, but if any have been inadvertently overlooked the publishers will be pleased to make the necessary amendment at the first opportunity. 